\title{
Haemolymph parasite of the shore crab Carcinus maenas: pathology, ultrastructure and observations on crustacean haplosporidians
}

\author{
G. D. Stentiford ${ }^{1}$, S. W. Feist ${ }^{1}$, K. S. Bateman ${ }^{1}$, P. M. Hine ${ }^{2, *}$ \\ ${ }^{1}$ Centre for Environment, Fisheries and Aquaculture Science (CEFAS), The Nothe, Weymouth, Dorset DT4 8UB, UK \\ ${ }^{2}$ National Centre for Disease Investigation, Ministry of Agriculture and Forestry, PO Box 40-742, Upper Hutt, New Zealand
}

\begin{abstract}
A protozoan parasite with some features of haplosporidians is described from the European shore crab Carcinus maenas. The parasite establishes a systemic infection through the haemal sinuses and connective tissues. Intracellular stages of the parasite were found within reserve inclusion, connective tissue, and muscle cells, while free forms were present in all haemal spaces. A uninucleate stage appeared to develop to a multinucleate plasmodial stage following multiple mitotic divisions of the nucleus. Histopathology also indicated that nuclear division may occur to form multinucleate plasmodia, in connective tissue, reserve inclusion and muscle cells, the multinucleate plasmodium being enclosed in the host-cell plasma membrane. It appears that the multinucleate plasmodium may then undergo internal cleavages which result in plasmodial fragmentation to form many uninucleate stages. Both stages, but particularly the uninucleate stage, contained cytoplasmic, large, ovoid, dense vesicles (DVs), some of which contained an internal membrane separating the medulla from the cortex, as in haplosporosomes. Golgi-like cisternae, closely associated with the nuclear membrane, formed DVs and haplosporosome-like bodies (HLBs), superficially resembling viruses. Infrequently, HLBs may condense to form haplosporosomes. The DVs, as in spores of some Haplosporidium spp. and paramyxeans, may give rise to, and are homologous with, haplosporosomes. Other features, such as the presence of an intranuclear mitotic spindle, lipid droplets, and attachment of DVs and haplosporosomes to the nuclear membrane, indicate that the C. maenas parasite is a haplosporidian. A similar organism reported from the haemolymph of spot prawns Pandalus spp., and haplosporidians reported from prawns Penaeus vannamei and crabs Callinectes sapidus may belong to this group. It is concluded that the well-characterised haplosporidians of molluscs and some other invertebrates may not be characteristic of the whole phylum, and that morphologically and developmentally similar organisms may also be haplosporidians, whether they have haplosporosomes or not.
\end{abstract}

KEY WORDS: Carcinus maenas $\cdot$ Haemolymph $\cdot$ Haplosporidian $\cdot$ Histopathology $\cdot$ Ultrastructure · Taxonomy

Resale or republication not permitted without written consent of the publisher

\section{INTRODUCTION}

Our knowledge of the Haplosporidia is largely based on haplosporidians infecting molluscs, although species such as Haplosporidium cadomensis (Marchand \& Sprague 1979), H. louisiana (Perkins 1975a), Claustrosporidium gammari (Larsson 1987), and unclassified forms apparently lacking spores (Newman et al. 1976, Dyková et al. 1988), have been reported from the crustaceans. H. cadomensis, H. louisiana, and Haplosporidium sp. (Rosenfield et al. 1969) from crabs may be conspecific species (Perkins \& van Banning 1981). To date, most studies have concentrated on molluscs, since some species such as $H$. nelsoni (Andrews \& Frierman 1974, Barber et al. 1997) and Bonamia spp. (Meuriot \& Grizel 1984, Grizel 1985, Doonan et al. 1994) cause epizootics. Consequently, the diseases that they cause have been listed by the OIE (Office International des Epizooties, of the World Animal Health Organization, Paris) as internationally notifiable diseases. The features that characterise the haplosporidians are currently unclear. Originally, possession of 
cytoplasmic dense bodies, called haplosporosomes, was regarded as characteristic of haplosporidians (Perkins 1979). However, haplosporosomes also occur in paramyxeans (Longshaw et al. 2001), a group that, on the basis of their multicellularity (Desportes 1984), cell-within-cell division (Desportes \& Perkins 1989), and a small subunit RNA gene sequence (CavalierSmith \& Chao 2003), has placed haplosporidians and paramyxeans in the phylum Cercozoa. However, they are ultrastructurally and developmentally very different, casting doubt on the phylogeny based on 1 gene sequence. Haplosporosomes also occur in the vegetative stages of some myxozoans (Morris et al. 2000), which are bilaterians (Okamura et al. 2002) not protists. Therefore, haplosporosomes are not by themselves of phylogenetic significance. It was also thought that the formation of spores, as in Haplosporidium spp., Minchinia spp. and Urosporidium spp., characterised the group, but Bonamia spp. including B. roughleyi lack spores, although they are haplosporidians (Carnegie et al. 2000, Cochennec-Laureau et al. 2003).

Parasites with haplosporosomes, but apparently lacking spores, have been reported from prawns Penaeus vannamei (Dyková et al. 1988) and crabs Callinectes sapidus (Newman et al. 1976), but in the absence of spores or details of their developmental cycles, their taxonomic position is unclear. An organism resembling dinoflagellates, but lacking characteristic organelles, such as trichocysts, has also been reported from spot prawns Pandalus spp. on the coasts of Alaska (Meyers et al. 1994) and western Canada (Bower \& Meyer 2002), and its taxonomic position is also unclear. This paper reports a parasite from shore crabs, Carcinus maenas (L.) from British waters, with features intermediate between the spot prawn parasite and the unclassified parasites of $P$. vannamei and Callinectes sapidus. It is suggested that all of these parasites are haplosporidians, differing in some features from those reported from molluscs.

\section{MATERIALS AND METHODS}

Shore crabs Carcinus maenas were captured from Newton's Cove, Weymouth, UK $\left(50^{\circ} 34^{\prime} \mathrm{N}, 2^{\circ} 22^{\prime} \mathrm{W}\right)$ between December 2001 and February 2002 using conventional baited parlour pots. Of the 70 crabs sampled $5(7.14 \%)$, all males (confirmed by histology), contained haemolymph of an opaque, creamy consistency that coated the internal organs and tissues. These crabs were morbid and appeared to be significantly less aggressive than their unaffected counterparts. Since the reason for collection was an attempt to redescribe Hematodinium perezi from C. maenas captured from the English Channel and based upon the appearance of the haemolymph and the internal organs, the external diagnosis of this condition was an Hematodinium spp. infection that has been shown to cause similar effects in other decapod crustaceans (Cancer pagurus and Necora puber) from this geographical region (Stentiford et al. 2002, 2003).

Histopathology. Crabs were anaesthetised by chilling to $4^{\circ} \mathrm{C}$. For histopathology, the hepatopancreas, gill, midgut, gonad, body muscle and claw muscle were removed from apparently healthy crabs and from those containing opaque, creamy haemolymph. Excised samples were placed immediately into Davidson's seawater fixative (Hopwood 1996). Fixation was allowed to proceed for $24 \mathrm{~h}$ before samples were transferred to $70 \%$ industrial methylated spirit for transportation and storage. All samples were processed within $7 \mathrm{~d}$ of collection. Fixed samples were processed to wax in a vacuum infiltration processor using standard protocols. Sections were cut at a thickness of 3 to $5 \mu \mathrm{m}$ on a rotary microtome and were mounted onto glass slides before staining with haematoxylin and eosin (HE). Stained sections were analysed by light microscopy (Nikon Eclipse E800) and digital images were taken using the Lucia ${ }^{\mathrm{TM}}$ Screen Measurement System (Nikon).

Electron microscopy. For electron microscopy, $2 \mathrm{~mm}^{3}$ blocks of tissue (as above) were fixed in a solution containing $2.5 \%$ glutaraldehyde in $0.1 \mathrm{M}$ sodium cacodylate buffer ( $\mathrm{pH} 7.4$ ), with $1.75 \%$ sodium chloride for $2 \mathrm{~h}$ at room temperature. Fixed tissue samples were rinsed in $0.1 \mathrm{M}$ sodium cacodylate buffer with $1.75 \%$ sodium chloride ( $\mathrm{pH} 7.4$ ) and post-fixed in $1 \%$ osmium tetroxide in $0.1 \mathrm{M}$ sodium cacodylate buffer for $1 \mathrm{~h}$ at $4^{\circ} \mathrm{C}$. Specimens were washed in 3 changes of $0.1 \mathrm{M}$ sodium cacodylate buffer and dehydrated through an acetone series. Specimens were embedded in epoxy resin 812 (Agar Scientific-pre-mix kit 812). Semithin sections (1 to $2 \mu \mathrm{m}$ ) were stained with Toluidine Blue for viewing with a light microscope. Suitable areas were identified and ultrathin sections (70 to $90 \mathrm{~nm}$ ) of these areas were cut and mounted on uncoated copper grids. Sections were stained with uranyl acetate and Reynolds lead citrate and were examined using a JEOL 1210 transmission electron microscope.

\section{RESULTS}

\section{Histopathology}

The haemal sinuses of crabs containing opaque, creamy haemolymph were congested with large, apparently multicellular, weakly eosinophilic aggregations, some of which contained a distinctive nucleus, possibly of host origin (Fig. 1). In the hepatopancreas 
and connective tissues surrounding the gut, these aggregations were associated with the reserve inclusion (RI) and other connective cells (Fig. 2) and often contained large eosinophilic inclusions (Fig. 3). In more advanced stages of infection, the connectivetissue matrix was disturbed with apparent fragmentation of the large multicellular aggregations to smaller aggregations and small single cells (see Fig. 1). Multicellular and unicellular stages could also be seen congesting the haemal spaces of the gill (Fig. 4) and the testis (Fig. 5), although in the latter case, these stages did not infiltrate the testicular lobes and did not appear to affect the production of normal spermatophores. Multicellular stages were also observed in the sub-sarcolemmal space of the claw and body musculature of mildly affected crabs (Fig. 6). In more severe cases, whole muscle fibres and fibre bundles were replaced with masses of multicellular stages (Fig. 7), while adjacent fibres and fibre bundles appeared apparently unaffected (Fig. 8). Despite the congested nature of the haemal sinuses and the significant departure from the normal haemolymph status of affected crabs, no obvious host immune-reaction (e.g. granuloma-like inflammatory lesions) appeared to be associated with either the multicellular or unicellular stages, although in some cases, small numbers of haemocytes were observed amongst free stages of the infecting organism (see Fig. 1). some cells appeared to be spherical, with electronlucent cytoplasm containing a single central nucleus with marginated heterochromatin and an eccentric nucleolus. Dense vesicles (DVs), haplosporosome-like bodies (HLBs) and ovoid lucent vesicles (OLVs) were also present (Fig. 12). Other cells were less spherical and contained a much denser cytoplasm (see Fig. 10). A clear margin separated the uninucleate cells from the bounding membrane (Fig. 11). In a few cells, DVs appeared to lie around and in contact with the nuclear membrane, similar to that observed in the multinucleate plasmodia (Fig. 14) and in some cases appeared to contain a lucent membrane underlying the surface membrane (see Fig. 12).

\section{Multinucleate plasmodial stage}

Multinucleate plasmodia varied greatly in size from small binucleate stages to larger multinucleate stages, containing up to 22 nuclei in section (Fig. 13, Table 1). In small plasmodia with few nuclei, the nuclei often occurred in pairs (Fig. 14) and in some cases appeared to be in contact with each other (Fig. 15). In several cases, the membranes of multinucleate plasmodia appeared to be in close association with those of adjacent plasmodia (see Fig. 15). While apparent host-cell nuclei were observed in multinucleate and

\section{Ultrastructure}

In the haemolymph and connective tissues of infected crabs, 3 stages were encountered: a free uninucleate stage, a multinucleate plasmodial stage and a membrane-bound multicellular plasmodial stage (containing uninucleate parasites with morphology similar to the free uninucleate stages). Morphological measurements of the various features of these stages are given in Table 1.

\section{Uninucleate stage}

Uninucleate stages of the parasite were present both free within the cytoplasm and, occasionally, within haemocytes (Fig. 9). Large numbers of uninucleate stages could also be contained within a plasma membrane, forming a multicellular plasmodium (Fig. 10). Within these plasmodia,
Table 1. Protozoan parasite of Carcinus maenas. Mean width, height and membrane measurements of uninucleate, multinucleate and multicellular parasite cells. Multicellular measurements refer to individual unicellular parasite cells within plasma membrane of multicellular plasmodia. na: not applicable

\begin{tabular}{|lrrr|}
\hline & Uninucleate & Multinucleate & Multicellular \\
\hline Cell & & & \\
Width $(\mu \mathrm{m})$ & $1.89 \pm 0.05$ & na & $1.98 \pm 0.04$ \\
Height $(\mu \mathrm{m})$ & $2.14 \pm 0.04$ & na & $1.96 \pm 0.03$ \\
Nucleus & & & \\
Width (nm) & $911.9 \pm 11.9$ & $1266.3 \pm 34.1$ & $860.4 \pm 19.2$ \\
Height (nm) & $944.9 \pm 16.7$ & $1369.9 \pm 34.5$ & $872.3 \pm 19.1$ \\
Dense vesicle (DV) & & & \\
Width (nm) & $125.5 \pm 2.07$ & $126.2 \pm 1.64$ & $130.6 \pm 2.05$ \\
Height (nm) & $141.2 \pm 2.23$ & $127.9 \pm 1.84$ & $140.0 \pm 2.32$ \\
Membrane (nm) & $9.6 \pm 0.29$ & $10.8 \pm 0.38$ & $9.9 \pm 0.24$ \\
Haplosporosome-like body (HLB) & & \\
Width (nm) & $125.9 \pm 1.81$ & $130.9 \pm 1.72$ & $123.5 \pm 1.66$ \\
Height (nm) & $138.9 \pm 2.32$ & $147.8 \pm 2.77$ & $139.5 \pm 1.82$ \\
Membrane (nm) & $11.6 \pm 0.44$ & $13.6 \pm 0.28$ & $9.9 \pm 0.24$ \\
HLB core & & & \\
Width (nm) & $85.4 \pm 1.37$ & $85.9 \pm 1.18$ & $89.7 \pm 1.22$ \\
Height (nm) & $93.4 \pm 1.48$ & $94.1 \pm 1.41$ & $99.2 \pm 1.33$ \\
Ovoid lucent vesicle (OLV) & & & \\
Width (nm) & $107.9 \pm 5.03$ & $110.0 \pm 3.18$ & $95.1 \pm 2.44$ \\
Height (nm) & $123.1 \pm 5.59$ & $125.9 \pm 3.42$ & $104.7 \pm 2.62$ \\
\hline
\end{tabular}




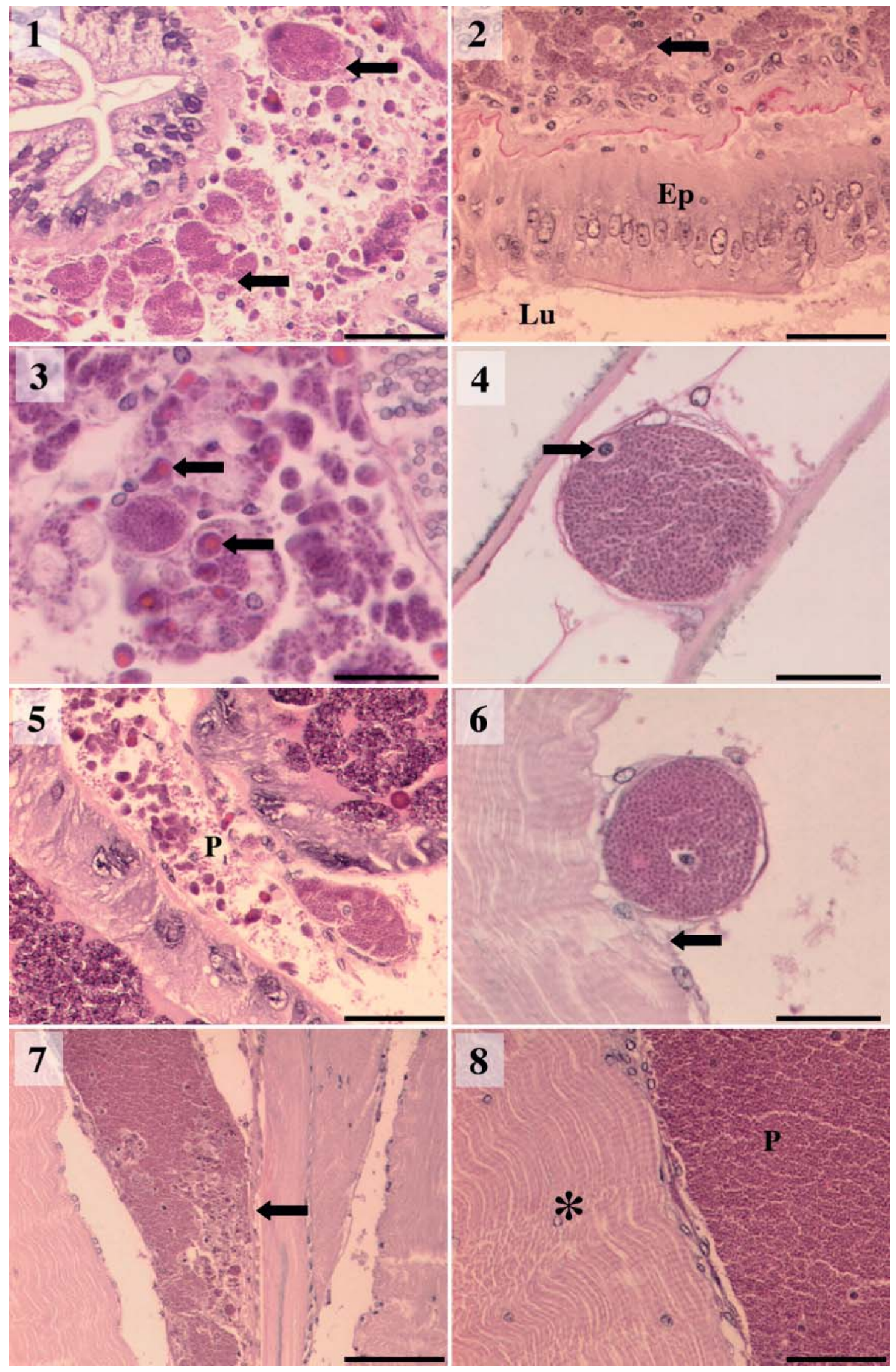


Figs. 1 to 8. Carcinus maenas infected by protozoan parasite (H\&E). Fig. 1. Hepatopancreas of infected crab showing congestion of haemal sinuses by multinucleate plasmodia (arrows); scale bar $=\overline{50 \mu \mathrm{m}}$. Fig. 2 . Mid-gut of infected crab showing unaffected epithelial lining (Ep), parasite-free lumen ( $\mathrm{Lu})$ and heavy infiltration of longitudinal and circular muscular by uninucleate and multinucleate parasites (arrow); scale bar $=50 \mu \mathrm{m}$. Fig. 3. Hepatopancreas of infected crab showing congestion of the haemal sinus and apparent infection of reserve inclusion cells (arrows); scale bar $=25 \mu \mathrm{m}$. Fig. 4 . Secondary gill lamella of infected crab showing intracellular infection of an epithelial or 'pillar' cell; host nucleus can also be observed (arrow); scale bar $=25 \mu \mathrm{m}$. Fig. 5. Testis of infected crab showing blockage of haemal sinuses by multinucleate plasmodia (P). Lumen of testis and adjoining

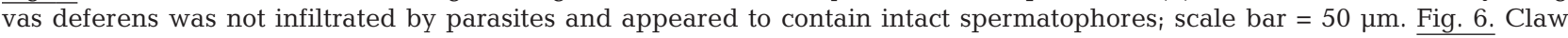
muscle of infected crab showing intracellular infection of sub-sarcolemmal space (arrow); this appeared to represent the early phase of muscle infection (cf. with Figs. $7 \&$ 8); scale bar $=25 \mu \mathrm{m}$. Fig. 7. Claw muscle of infected crab showing replacement of individual muscle fibres and fibre bundles by parasites; attachment to apodeme is still present (arrow); scale bar $=100 \mu \mathrm{m}$. Fig. 8. Claw muscle of infected crab showing complete replacement of muscle tissue with parasites (P); adjacent fibres appeared unaffected (asterisk); scale bar $=50 \mu \mathrm{m}$

multicellular plasmodia in histopathological sections (see Figs. 1, 3, 4 \& 6), no host nuclei were observed in specimens prepared for electron microscopy. DVs were frequently arrayed around and in contact with nuclear membranes (Fig. 16). In these stages, nuclei frequently contained several intranuclear microtubules attached by plaques to the inner nuclear membrane at opposite ends of the nucleus (Fig. 17). Occasionally in the cytoplasm, a simple Golgi apparatus comprising 1 to 3 cisternae, that often had a beaded appearance, lay close to and around the nuclear membrane (Fig. 18). HLBs and DVs, similar to those in the uninucleate stage, appeared to be formed at the ends of these cisternae (see Fig. 18). HLBs with an angular or roughly hexagonal outer membrane, enclosing an inner core that was also membranebound, were common in the cytoplasm and resembled viral particles (see Fig. 12). DVs, with or without an inner membrane and OLVs were also common in the cytoplasm. Mitochondria and a few lipid droplets were also present. Ribosomes were rarely observed in large plasmodia, but this may have been due to poor fixation. In some cases, membrane formation occurred around discrete nuclei, enclosing DVs, HLBs and OLVs (Fig. 19). This appeared to result in the formation of unicellular stages of the parasite and presumably pre-empted the formation of the multicellular plasmodia.

In several cases, agranular haemocytes appeared to have phagocytosed and attempted to destroy uninucleate and small multinucleate stages of the parasite. In these cases, the cytoplasm of the haemocyte contained parasites in various states of degeneration and membranous whorls, presumably of parasite origin (Fig. 20).

\section{DISCUSSION}

This paper provides the first description of a haplosporidian-like parasite infecting the haemolymph and connective tissues of European shore crabs Carcinus maenas captured in the English Channel. From gross observations, and in accordance with the internal appearance of organs and tissues, infected crabs were initially thought to be harbouring the parasite Hematodinium perezi, a parasite similar to that described infecting Cancer pagurus and Necora puber from the same location (Stentiford et al. 2002, 2003). However, histopathological and ultrastructural observations of infected crabs revealed severe obstruction of haemal sinuses by masses of mononuclear parasites, multi-nucleate and multicellular plasmodial forms. In addition, the connective-tissue cells and RI cells appeared to harbour intracellular infections. Intracellular infection led to complete destruction of the connective-tissue matrix (particularly within the hepatopancreas) and to a loss of RI cells. Although physiological measurements were not made, the departure from normal haemocytology coupled with severe tissue congestion is likely to have led to hypoxia in infected crabs and we presume that infection with this parasite is fatal. Due to the severe pathology associated with infection, a prevalence of over $7 \%$ may indicate that this parasite should be considered a mortality factor in populations of Carcinus maenas where it is endemic.

The identity of the systemic uni- and multicellular organisms could not be determined from light microscopy, and therefore an ultrastructural investigation was undertaken. The latter revealed organisms that could not be readily identified as belonging to a known group of protozoans. However, the parasite resembled some of the stages of the organism reported from spot prawns by Bower \& Meyer (2002), but had some features, particularly the multinucleate plasmodium, similar to haplosporidians. Ultrastructural observations were therefore compared with haplosporidians, particularly those species infecting crustaceans (Newman et al. 1976, Dyková et al. 1988), and with the spot prawn parasite (Bower \& Meyer 2002). 


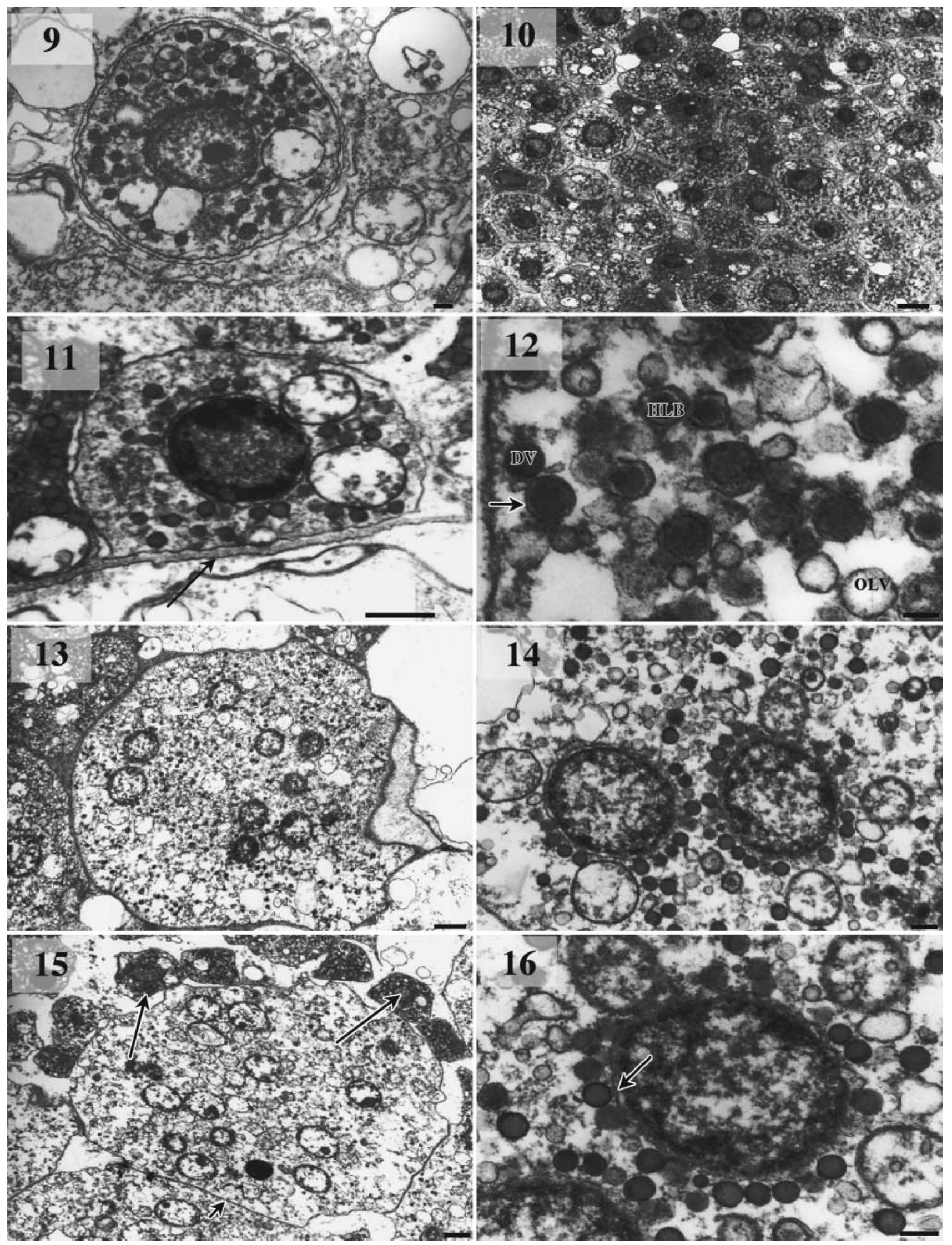


Figs. 9 to 16. Protozoan parasite of Carcinus maenas (TEM). Fig. 9. Uninucleate parasite within a haemocyte; parasite shows a prominent nucleolus within the nucleus, mitochondria, dense vesicles, haplosporosome-like bodies and ovoid lucent vesicles, all bound within a clear membrane (as in Fig. 12); scale bar $=200 \mathrm{~nm}$. Fig. 10. Multicellular plasmodium showing large aggregation of uninucleate parasites bound within plasma membrane; uninucleate parasites contain nuclei, mitochondria, DVs, HLBs and OLVs; some parasites are less spherical and have a denser cytoplasm than others: scale bar $=1 \mu$ m. Fig. 11 . Uninucleate parasite within multicellular plasmodium; a clear margin can be seen between membrane of uninucleate parasite and the plasma membrane (arrow); scale bar $=500 \mathrm{~nm}$. Fig. 12. DV, HLB and OLV within cytoplasm of a uninucleate parasite; some DVs appeared to contain a lucent membrane underlying surface membrane (arrow); HLBs resembled viruses, with a roughly hexagonal outer membrane enclosing an inner core which was also membrane bound; scale bar $=100 \mathrm{~nm}$. Fig. 13. Multinucleate plasmodia containing mitochondria, DVs, HLBs and OLVS; scale bar $=1 \mu \mathrm{m}$. Fig. 14. Higher magnification of multinucleate plasmodium; nuclei were sometimes observed in pairs with DVs surrounding nuclei; scale bar $=200 \mathrm{~nm}$. Fig. 15. Multinucleate plasmodium showing closely associated nuclei; plasmodium is surrounded by free uninucleate parasites (long arrows) and appears to have close association with adjacent plasmodia (short arrow); scale bar $=1 \mu \mathrm{m}$. Fig. 16. Single nucleus within multinucleate plasmodium; DVs are shown surrounding and in close association with nuclear membrane (arrow); scale bar $=200 \mathrm{~nm}$

\section{The Carcinus maenas parasite as a haplosporidian}

There is no single ultrastructural feature that characterises haplosporidians that has not been reported in other protozoans. Haplosporidians are therefore recognised on the presence of a combination of features. These include a uninucleate stage, usually with a cen- tral nucleus which develops to a diplokaryotic stage in which 2 nuclei lie close and in contact with each other after division, sometimes with a small internuclear chamber (Perkins 1975a, Marchand \& Sprague 1979). Further nuclear division produces multinucleate plasmodia, from which operculate spores may develop. A persistent mitotic spindle is usually present (Perkins

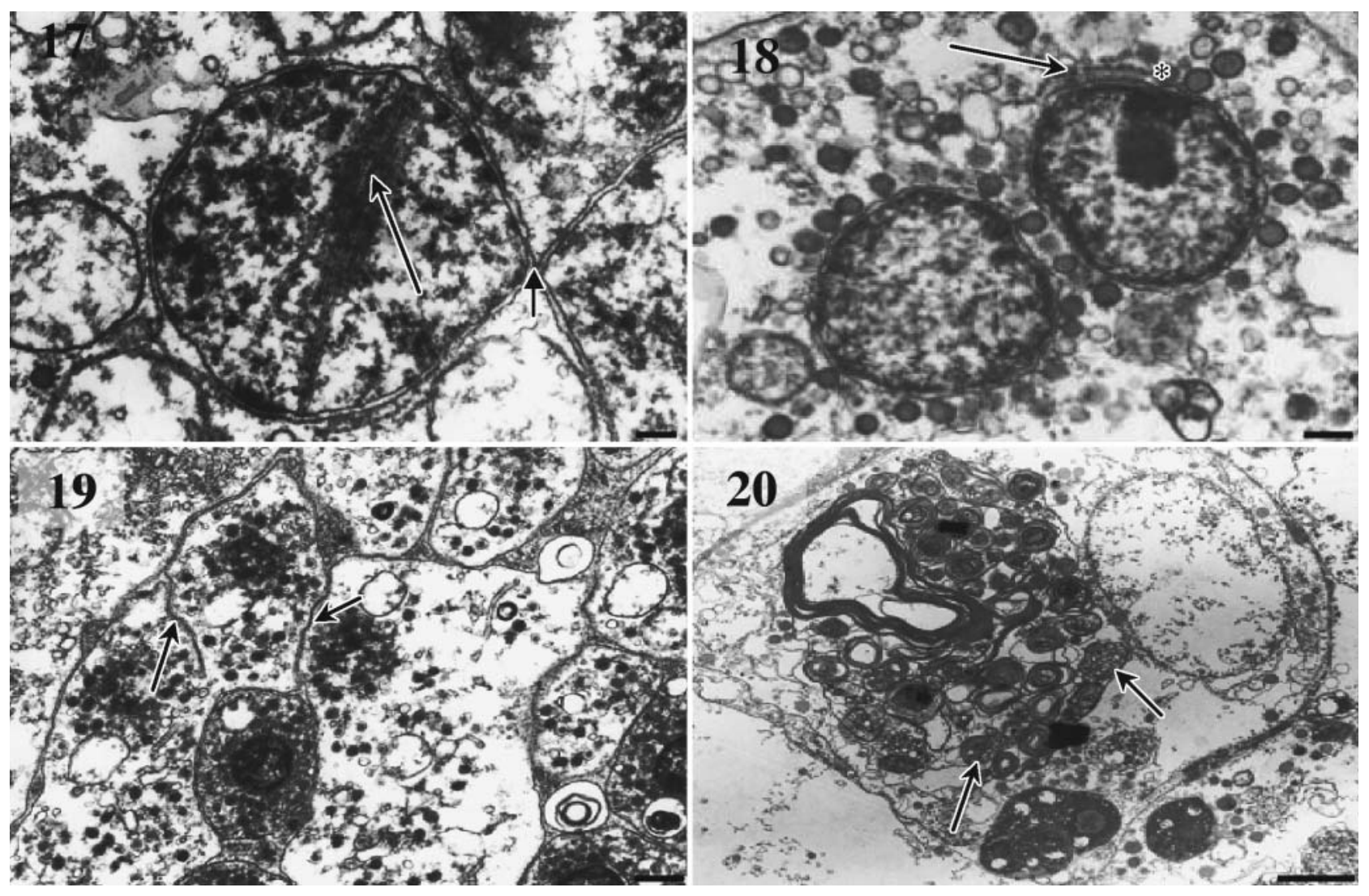

Figs. 17 to 20. Protozoan parasite of Carcinus maenas (TEM). Fig. 17. Single nucleus within a multinucleate plasmodium. Intranuclear microtubules can be seen within nucleus (long arrow); nucleus also appears to be in close association with an adjacent nucleus (short arrow); scale bar $=200 \mathrm{~nm}$. Fig. 18. Nuclei within a multinucleate plasmodium with Golgi apparatus at the nuclear membrane (arrow); DVs appear to be produced by the cisternae (asterisk); scale bar $=200 \mathrm{~nm}$. Fig. 19. Multinucleate plasmodium showing apparent transition to production of unicellular parasites; membrane-like structures (arrow) are seen forming around nuclei and associated mitochondria, DVs, HLBs and OLVs: scale bar $=500 \mathrm{~nm}$. Fig. 20. Haemocyte containing extensive membranous whorls; uninucleate stages of parasites can be seen in various states of degeneration within these whorls (arrows); scale bar $=2 \mu \mathrm{m}$ 
1975b), and granular material may lie in pits on the nuclear surface (Perkins 1969, Hine \& Wesney 1992). Cytoplasmic organelles include lipid droplets (Hine \& Wesney 1994), sparse endoplasmic reticulum (ER) and ribosomes, haplosporosomes or homologous structures, and nuclear membrane-bound Golgi (NBG) (Perkins 1979, Hine \& Wesney 1992, Hine et al. 2002). In vegetative stages, haplosporogenesis may involve production of haplosporosome-like bodies (HLBs) or haplosporosomes from NBG (Hine et al. 2002), from unattached Golgi in the cytoplasm (Hine \& Wesney 1992), or, as in Haplosporidium nelsoni, from cytoplasmic granular masses (Perkins 1968, 1979), possibly originating from the nucleoplasm. Similarly, in sporogenesis, haplosporosomes may be formed from DVS (Hine \& Thorne 2002), or granular matter originating from the spherulosome (Hine \& Thorne 1998), or directly from the spherulosome (Azevedo \& Corral 1987).

Not all these features carry the same weight. Uninucleate stages develop to multinucleate stages in other protozoans. Diplokarya are common in haplosporidians, but they are also ubiquitous in microsporans, and are common in myxozoans. A molecular study on the microsporan genus Pleistophora using small subunit (ssu) rDNA sequences, has shown that several of the ultrastructural features by which fish-infecting species have been classified, including the diplokaryon, are polyphyletic, having arisen several times during evolution (Nilsen et al. 1998). The same might also be the case within the haplosporidians. Currently, the 2 most reliable features for distinguishing haplosporidians are the production of the characteristic operculate spores, and the method of haplosporogenesis in those species which do not produce spores.

The haplosporidian features present in the Carcinus maenas parasite include the uninucleate and multinucleate stages, lipid droplets, sparse ribosomes and ER, the NBG and production of DVs and HLBs from the NBG, and the presence of a few haplosporosomes. The production of DVs and HLBs from the NBG, and the large number of DVs, some with an internal membrane resembling haplosporosomes, raises the question of the identity of the DVs. The DVs of the spot prawn parasite are larger than haplosporosomes and appear to lack an internal membrane, and in this study, most DVs also did not appear to possess such a membrane. However, some DVs were divided into a less dense medulla and denser cortex, separated by a membrane 2.5 to $5.0 \mathrm{~nm}$ across (Fig. 12), similar to haplosporosomes. The DVs lacking an internal structure characteristic of haplosporosomes resemble those reported from Minchinia dentali by Desportes \& Nashed (1983), M. teredinis by Hillman et al. (1990), Haplosporidium comatulae by La Haye et al. (1984), and 2, possibly conspecific, species infecting crabs, $H$. cadomensis by
Marchand \& Sprague (1979) and H. louisiana by Rosenfield et al. (1969) and Perkins (1975a). They may also correspond to the 'organites' of $H$. parisi spores (Ormières 1980). The inclusion bodies in H. ascidiarum (Ormières \& de Puytorac 1968, Ciancio et al. 1999) may also correspond to DVs, but their association with surrounding $E R$ is similar to that seen around lipid droplets in Bonamia exitiosa (= Bonamia sp.) (Hine \& Wesney 1994). However, they are also closely associated with the spherulosome, as are DVs, so their identity is unclear. In $M$. teredinis, $H$. cadomensis, $H$. louisiana, and Haplosporidium sp., haplosporosomes develop from the DVs (Perkins 1975a, Marchand \& Sprague 1979, Hillman et al. 1990, Hine \& Thorne 1998). However, in $M$. dentali, Minchinia sp., $H$. comatulae, and $H$. parisi, they remain as DVs (Ormières 1980, Desportes \& Nashed 1983, La Haye et al. 1984, Comps \& Tigé 1997), without the production of haplosporosomes. It is likely that DVs, inclusion bodies and organites are all part of the haplosporosome developmental cycle, including the DVs of the spot prawn parasite.

The large ovoid cytoplasmic DVs observed here did not closely resemble haplosporosomes, but their formation is typical of haplosporogenesis from NBG, as seen in Haplosporidium nelsoni (see Perkins 1979), Urosporidium spisuli (see Perkins 1979), Bonamia exitiosus (Hine \& Wesney 1992), a haplosporidian infecting abalone (Hine et al. 2002), and an unidentified haplosporidian (Bonami et al. 1985). It appears that HLBs seldom condensed to form haplosporosomes in the Carcinus maenas parasite (CMP). The close contact of DVs and haplosporosomes with and around the nuclear membrane is similar to that reported from $H$. ascidiarum by Ciancio et al. (1999), and from uninucleate stages of apparently non spore-forming haplosporidians from Penaeus vannemai, a prawn (Dyková et al. 1988), and Callinectes sapidus, a crab (Newman et al. 1976).

\section{Relationship of spot prawn parasite to the Carcinus maenas parasite to haplosporidians}

The spot prawn parasite differs from the Carcinus maenas parasite in the method of mitosis, and in the presence of nucleus-associated organelles, plasmalemma extensions, and basophilic inclusion bodies (Bower \& Meyer 2002). The method of mitosis may be less important than imagined. Protozoan mitosis can be divided into pleuromitosis, in which the spindle is eccentric and the whole mitotic apparatus is bilaterally symmetrical, and orthomitosis, in which there is axial symmetry at metaphase (Raikov 1994). These 2 types are sub-divided into closed (nuclear membrane persists 
throughout mitosis), semi-open (nuclear membrane persists, but breaks down and opens at the poles), and open (nuclear membrane is completely dispersed). Closed mitosis and pleuromitosis are regarded as more primitive than open mitosis and orthomitosis. In Syndinium sp., a dinoflagellate which has been compared with the spot prawn parasite (Bower \& Meyer 2002), division is by closed extranuclear pleuromitosis (Raikov 1994). To date, mitosis in the Haplosporidia has been consistently reported as closed (Perkins 1975a,b, Azevedo et al. 1985, Hine et al. 2001), but whether it is closed pleuromitosis (Raikov 1994) or closed orthomitosis is difficult to determine on the limited data available. Mitosis in the spot prawn parasite is semiopen pleuromitosis or orthomitosis, but this does not necessarily exclude the spot prawn parasite from the Haplosporidia. There is only a weak association between phylogeny and mitosis in the Protozoa, with the variables described above being interrelated rather than totally separate processes (Raikov 1994). Some groups use more than one method of mitosis during their life cycles, or they start division by one method involving an intact nuclear membrane, and later change to another method with a dispersed nuclear membrane. Most apicomplexans divide by semi-open pleuromitosis, but the gregarines genera Deplauxi and Lecudina, use semi-open orthomitosis, and the genera Monocystis and Stylocephalus, also gregarines, use open orthomitosis. Prasinomonad algal flagellates divide by closed intranuclear pleuromitosis or open orthomitosis (Raikov 1994). There is also variation within haplosporidians, as Haplosporidium nelsoni (Perkins 1975b) and Bonamia exitiosa (Hine et al. 2001) have persistent mitotic spindles, while spindles were not apparent in the abalone haplosporidian (Hine et al. 2002), and therefore they are not necessarily persistent.

The Carcinus maenas parasite was similar to the spot prawn parasite in infecting and discolouring the haemolymph of crustaceans, in general appearance of the uninucleate stages, in their development into multinucleate plasmodia which undergo fragmentation to form large numbers of the uninucleate stage, and in the occurrence of membrane whorls (Bower \& Meyer 2002). There are also many differences between the $C$. maenas parasite and the spot prawn parasite, suggesting that, while they may be related, they do not appear to be closely related.

\section{Comparison of Carcinus maenas parasite, spot prawn parasite and haplosporidian development cycles}

A simplified diagram of possible relationships and development cycles among haplosporidians is shown in Fig. 21. It is likely that all species have a simple uninucleate stage (A) that develops into a diplokaryon (B). In Bonamia spp., this may give rise to a small binucleate or multinucleate plasmodium $\left(\mathrm{C}_{\mathbf{i}}\right.$ Brehélin et al. 1982) that probably undergoes schizogony to form more uninucleate stages (D), thus completing a developmental cycle in which haplosporosomes are present at every stage of the cycle. Similar schizogony occurs in the haplosporidian B. roughleyi, which has an $18 \mathrm{~S}$ base sequence closely resembling Bonamia spp. (Cochennec-Laureau et al. 2003). The prawn and crab parasites probably go through a similar cycle, but the multinucleate plasmodia are larger $\left(E_{;}\right.$Newman et al. 1976, Fig. 6 in Dyková et al. 1988), as in spore-forming species (E to $\mathrm{M}$ and $\mathrm{N}_{\text {; }}$ Perkins 1968, 1969, 1975a, La Haye et al. 1984, Azevedo et al. 1985, Hine \& Thorne 1998), and the uninucleate bodies formed by schizogony (Dyková et al. 1988) may utilise an alternative host. The Carcinus maenas parasite also has a multinucleate plasmodium in which large number of uni-nucleate stages may be formed by schizogony (Fig. 19), in a stage equivalent to a sporont (H), to form a sporo-blast-like stage (J), as in spore-forming haplosporidians (see Fig. 12 in Perkins 1969. Fig. 16 in Perkins 1975a, Fig. 3 in Ciancio et al. 1999). The uninucleate stages so formed may again develop into multinucleate plasmodia, or they may be passed out from the host. The sporoblast-like stage (J) differs from the similar stage in crabs and prawns (F) in that the latter possesses haplosporosomes while the sporoblasts do not.

Among spore-forming species, it appears that Haplosporidium ascidiarum and $H$. lusitanicum may have developmental cycles similar to the Carcinus maenas parasite, but the sporoblasts (J; Fig. 4 in Ciancio et al. 1999, Figs. 14 \& 15 in Azevedo et al. 1985) go on to form spores by a process in which the spore wall develops within the sporoblast cytoplasm (M; Fig. 11 in Ciancio et al. 1999, Azevedo et al. 1985). Another distinctive form of spore formation involves a binucleate sporont becoming uninucleate by the loss of 1 nucleus or fusion of the nuclei $(I, J)$, the remaining nucleus migrating to one end of the sporoblast $(\mathrm{K})$. A constriction of the cytoplasm at the middle of the cell is followed by envelopment of the nucleate end (sporoplasm) by the cytoplasm at the other end (episporoplasm) (L), as in H. cadomensis (Fig. 8 in Marchand \& Sprague 1979), H. comatulae (Fig. 5 in La Haye et al. 1984), Minchina dentali (Figs. 24 to 26 in Desportes \& Nashed 1983), and Urosporidium jiroveci (Fig. 11 in Ormières et al. 1973). It is notable that this distinctive process occurs across the spore-forming genera, rather than being characteristic of a genus.

Exsporulation within the host and repeated developmental cycles may increase infection intensity, as exsporulation has been reported from Minchina dentali 


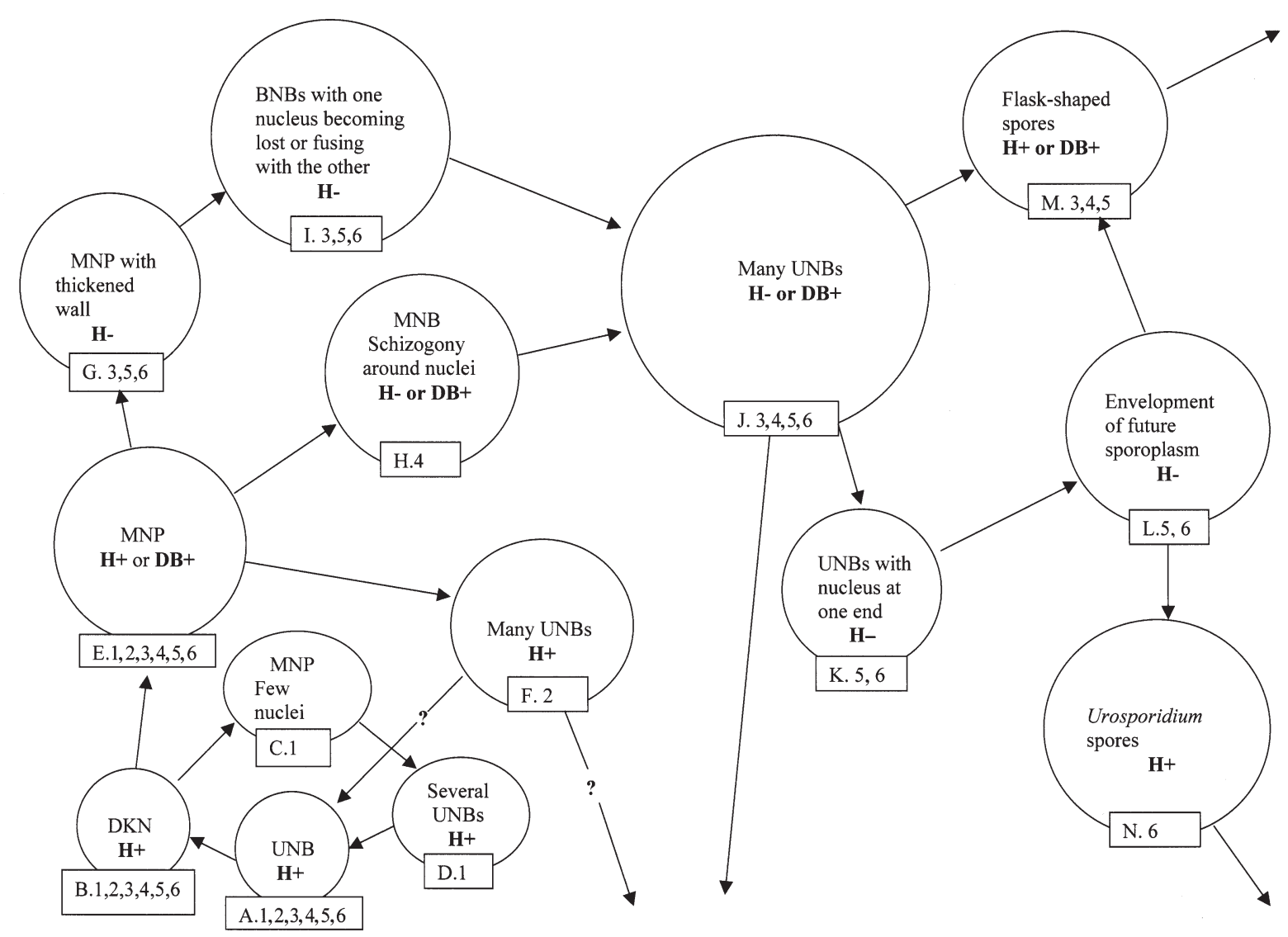

Fig. 21. Putative interrelationship of haplosporidians from molluscs and crustaceans. Arrows leading from images indicate dispersal. See text for interpretation of the figure. UNBs: uninucleate bodies; BNBs: binucleate bodies; MNP: multinucleate plasmodium; MNB: multinucleate body; DKN: diplokaryon; H-: haplosporosomes absent; H+: haplosporosomes present; DB+: dense bodies present; 1: Bonamia spp.; 2: Carcinus maenas parasite and spot prawn parasite; 3: Haplosporidium nelsoni and H. costale; 4: H. ascidiarum and H. lusitanicum; 5: H. cadomensis, H. comatuli and Minchina dentali; 6: Urosporidium jiroveci

(Desportes \& Nashed 1983), Haplosporidium lusitanicum (Azevedo et al. 1985, Azevedo \& Corral 1989) and Haplosporidium sp. (Hine \& Thorne 2002). Reduction of the developmental cycle to exclude sporulation, as in Bonamia spp., may allow more rapid cycling within the host and effective horizontal transmission. The Carcinus maenas parasite and the spot prawn parasite appear to fall between the abbreviated development of Bonamia spp. and complete sporulation of sporeforming species, with rapid recycling, but not horizontal transmission (Bower \& Meyer 2002). Retention of sporulation by spore-forming species must give some compensatory advantage, possibly dispersal over large distances as, in form, Haplosporidium spp. and Minchinia spp. spores resemble monogenean eggs, which are the dispersal phase.

As there are many similarities between the Carcinus maenas parasite and the spot prawn parasite, as the $C$. maenas parasite has ultrastructural features of a haplosporidian, and as spot prawn parasite actin and ssu rRNA gene sequences place it in the Haplosporidia
(Reece et al. 2000), on phenotypic and genotypic evidence the spot prawn parasite is a haplosporidian. However, the spot prawn parasite does not resemble molluscan haplosporidians, and one of us (P.M.H.) who examined electron micrographs of the spot prawn parasite did not recognise it as a haplosporidian. This may be because our concept of haplosporidians is largely based on molluscan haplosporidians, or those that resemble them, and these may not be characteristic of all the phylum Haplosporidia. The taxonomy of the Haplosporidia was initially too inclusive, with all organisms with haplosporosomes being included, and then too exclusive, with all non-spore-forming haplosporidians being excluded. This study, and largely forgotten studies on non-molluscan haplosporidians, show that there is considerable variation in the appearance of and developmental processes in haplosporidians. Ultrastructural and molecular studies on similar organisms in host groups other than molluscs may well broaden our recognition and understanding of the phylum Haplosporidia. 
Acknowledgements. The authors acknowledge the assistance of Mr. Matthew Evans for assistance with tissue preparations and histology, Mr. Kelvin Moore for obtaining crabs using baited pots, The Department of Environment, Food and Rural Affairs (Defra) of the United Kingdom for funding (under contract F1137) to G.D.S., S.W.F. and K.S.B. and to the Ministry of Agriculture and Forestry, New Zealand for funding to P.M.H.

\section{LITERATURE CITED}

Andrews JD, Frierman M (1974) Epizootiology of Minchinia nelsoni in susceptible wild oysters in Virginia, 1959-1970. J Invertebr Pathol 24:127-140

Azevedo C, Corral L (1987) Fine structure, development and cytochemistry of the spherulosome of Haplosporidium lusitanicum (Haplosporida). Eur J Protistol 23:89-94

Azevedo C, Corral L (1989) Fine structural observations of the natural spore excystment of Minchinia sp. (Haplosporida). Eur J Protistol 24:168-173

Azevedo C, Corral L, Perkins FO (1985) Ultrastructural observations of spore excystment, plasmodial development and sporoblast formation in Haplosporidium lusitanicum (Haplosporida, Haplosporidiidae). Z Parasitenkd 71:715-726

Barber BJ, Langan R, Howell TL (1997) Haplosporidium nelsoni (MSX) epizootic in the Piscataqua River estuary (Maine/New Hampshire, USA). J Parasitol 83:148-150

Berthe FC, Le Roux F, Peyretaillade E, Peyret P, Rodriguez D, Gouy M, Vivares CP (2000) Phylogenetic analysis of the small subunit ribosomal RNA of Marteilia refringens validates the existence of the phylum Paramyxea (Desportes \& Perkins, 1990). J Eukaryot Microbiol 47:288-293

Bonami JR, Vivarès CP, Brehélin M (1985) Étude d'une nouvelle haplosporidie parasite de l'huître plate Ostrea edulis L.: morphologie et cytologie de différents stades. Protistologica 21:161-173

Bower SM, Meyer GR (2002) Morphology and ultrastructure of a protistan pathogen in the haemolymph of shrimp (Pandalus spp.) in the northern Pacific Ocean. Can J Zool 80:1055-1068

Brehélin M, Bonami JR, Cousserans F, Vivarès CP (1982) Existence de formes plasmodiales vraies chez Bonamia ostreae parasite de l'huître plate Ostrea edulis. C R Acad Sci Sér III Sci Vie 295:45-48

Carnegie RB, Barber BJ, Culloty SC, Figueras AJ, Distel DL (2000) Development of a PCR assay for detection of the oyster pathogen Bonamia ostreae and support for its inclusion in the Haplosporidia. Dis Aquat Org 42:199-206

Cavalier-Smith T, Chao EY (2003) Phylogeny of Choanozoa, Apusozoa and other protozoa and early eukaryotic megaevolution. J Mol Evol 56:540-563

Ciancio A, Srippa S, Izzo C (1999) Ultrastructure of vegetative and sporulation stages of Haplosporidium ascidiarium from the ascidian Ciona intestinalis L. Eur J Protistol 35: $175-182$

Cochennec-Laureau N, Reece KS, Berthe FCJ, Hine PM (2003) Mikrocytos roughleyi: taxonomic affiliation points to the genus Bonamia (Haplosporidia). Dis Aquat Org 54:209-217

Comps M, Tigé G (1997) Fine structure of Minchinia sp., a haplosporidan infecting the mussel Mytilus galloprovincialis. Syst Parasitol 38:45-50

Desportes I (1984) The Paramyxea Levine 1979: an original example of evolution towards multicellularity. Origins Life 13:343-352

Desportes I, Nashed NN (1983) Ultrastructure of sporulation in Minchinia dentali (Arvy), an haplosporean parasite of Dentalium entale (Scaphopoda, Mollusca); taxonomic implications. Protistologica 19:435-460

Desportes I, Perkins FO (1989) Phylum Paramyxea. In: Margulis L, Corliss JO, Melkonian M, Chapman DJ (eds) Handbook of Protoctista. Jones \& Bartlett, Boston, p 30-35

Doonan IJ, Cranfield HJ, Michael KP (1994) Catastrophic reduction of the oyster, Tiostrea chilensis (Bivalvia: Ostreidae), in Foveaux Strait, New Zealand, due to infestation by the protistan Bonamia sp. NZ J Mar Freshw Res 28: $335-344$

Dyková I, Lom J, Fajer E (1988) A new haplosporean infecting the hepatopancreas in the penaeid shrimp, Penaeus vannamei. J Fish Dis 11:15-22

Grizel H (1985) Étude des recentes epizooties de l'huître plate Ostrea edulis Linné et de leur impact sur l'ostreiculture Bretonne, Thèse, Academie de Montpellier, Université des Sciences et Techniques du Languedoc

Hillman RE, Ford SE, Haskin HH (1990) Minchinia teredinis n.sp. (Balanosporida, Haplosporidiidae), a parasite of teredinid shipworms. J Protozool 37:364-368

Hine PM, Thorne T (1998) Haplosporidium sp. (Haplosporidia) in hatchery-reared pearl oysters, Pinctada maxima (Jameson, 1901), in north Western Australia. J Invertebr Pathol 71:48-52

Hine PM, Thorne T (2002) Haplosporidium sp. (Alveolata: Haplosporidia) associated with mortalities among rock oysters (Saccostrea cuccullata Born, 1778) in north Western Australia. Dis Aquat Org 51:123-133

Hine PM, Wesney B (1992) Interrelationships of cytoplasmic structures in Bonamia sp. (Haplosporidia) infecting oysters Tiostrea chilensis: an interpretation. Dis Aquat Org 14: $59-68$

Hine PM, Wesney B (1994) The functional cytology of Bonamia sp. (Haplosporidia) infecting oysters (Tiostrea chilensis): an ultracytochemical study. Dis Aquat Org 20: 207-217

Hine PM, Cochennec-Laureau N, Berthe FCJ (2001) Bonamia exitiosus n. sp. (Haplosporidia) infecting flat oysters Ostrea chilensis in New Zealand. Dis Aquat Org 47:63-72

Hine PM, Wakefield S, Diggles BK, Webb VL, Maas EW (2002) The ultrastructure of a haplosporidian containing Rickettsiae, associated with mortalities among cultured paua Haliotis iris Martyn, 1784. Dis Aquat Org 49:207-219

Hopwood D (1996) Fixation and fixatives. In: Bamcroft JD, Stevens A (eds) Theory and practice of histopathological techniques, 4th edn. Churchill Livingstone, Hong Kong, p 23-46

La Haye CA, Holland ND, McLean N (1984) Electron microscopic study of Haplosporidium comatulae n. sp. (phylum Ascetospora: class Stellatosporea), a haplosporidian endoparasite of an Australian crinoid, Oligometra serripinna (phylum Echinodermata). Protistologica 20:507-515

Larsson JIR (1987) On Haplosporidium gammari, a parasite of the amphipod Rivulogammarus pulex, and its relationships with the phylum Ascetospora. J Invertebr Pathol 49: 159-169

Longshaw M, Feist SW, Matthews RA, Figueras A (2001) Ultrastructural characterization of Marteilia species (Paramyxea) from Ostrea edulis, Mytilus edulis and Mytilus galloprovincialis in Europe. Dis Aquat Org 44:137-142

Marchand J, Sprague V (1979) Ultrastructure de Minchinia cadomensis sp.n. (Haplosporida) parasite du décapode Rhithropanopeus harrisii tridentatus Maitland dans le canal de Caen à la mer. J Protozool 26:179-185

Meuriot E, Grizel H (1984) Note sur l'impact economique des maladies de l'huitre plate en Bretagne. Rapp Tech ISTPM. Nantes France Institut Francais de Recherche pour 
l'Exploitation de la Mer, Centre de Nantes, No. 12

Meyers TR, Lightner DV, Redman RM (1994) A dinoflagellate-like parasite in Alaskan spot shrimp Pandalus platyceros and pink shrimp P. borealis. Dis Aquat Org 18:71-76

Morris DJ, Adams A, Richards RH (2000) Observations on the electron-dense bodies of the PKX parasite, agent of proliferative kidney disease in salmonids. Dis Aquat Org 39: 201-209

Newman MW, Johnson CA, Pauley GB (1976) A Minchinialike haplosporidan parasitizing blue crabs, Callinectes sapidus. J Invertebr Pathol 27:311-315

Nilsen F, Endresen C, Hordvik I (1998) Molecular phylogeny of microsporidians with particular reference to species that infect muscles of fish. J Eukaryot Microbiol 45: 535-543

Okamura B, Curry A, Wood TS, Canning EU (2002) Ultrastructure of Buddenbrockia identifies it as a myxozoan and verifies the bilateral origin of the Myxozoa. Parasitology 124:215-223

Ormières R (1980) Haplosporidium parisi n.sp. haplosporidie parasite de Serpula vermicularis L. étude ultrastructurale de la spore. Protistologica 16:467-474

Ormières R, de Puytorac P (1968) Ultrastructure des spores de l'haplosporidie Haplosporidium ascidiarium endoparasite du tunicier Sydnium elegans Giard. C R Hebd Séances Acad Sci Sér D 266:1134-1136

Ormières R, Sprague V, Bartoli P (1973) Light and electron microscope study of a new species of Urosporidium (Haplosporida), hyperparasite of trematode sporocysts in the clam Abra ovata. J Invertebr Pathol 21:71-86

Perkins FO (1968) Fine structure of the oyster pathogen Minchinia nelsoni (Haplosporida, Haplosporidiidae). J Invertebr Pathol 10:287-307

Perkins FO (1969) Electron microscope studies of sporulation in the oyster pathogen, Minchinia costalis (Sporozoa:

Editorial responsibility: Timothy Flegel,

Bangkok, Thailand
Haplosporida). J Parasitol 55:897-920

Perkins FO (1975a) Fine structure of Minchinia sp. (Haplosporida) sporulation in the mud crab, Panopeus herbstii. Mar Fish Rev 37:46-60

Perkins FO (1975b) Fine structure of the haplosporidan KERNSTAB, a persistent, intranuclear mitotic apparatus. J Cell Sci 18:327-346

Perkins FO (1979) Cell structure of shellfish pathogens and hyperparasites in the genera Minchinia, Urosporidium, Haplosporidium and Marteilia-taxonomic implications. Mar Fish Rev 1:25-37

Perkins FO, van Banning P (1981) Surface ultrastructure of spores in three genera of Balanosporida, particularly Minchinia armoricana van Banning, 1977. The taxonomic significance of spore wall ornamentation in the Balanosporida. J Parasitol 67:866-874

Raikov IB (1994) The diversity of forms of mitosis in Protozoa: a comparative review. Eur J Protistol 30:253-269

Reece KS, Burreson EM, Hudson KL, Bower SM, Dungan CF (2000) Molecular analysis of a parasite in prawns (Pandalus platyceros) from British Columbia, Canada. J Shellfish Res 19:647

Rosenfield A, Buchanan L, Chapman GB (1969) Comparison of the fine structure of spores of three species of Minchinia (Haplosporida, Haplosporidiidae). J Parasitol 55:921-941

Stentiford GD, Green M, Bateman K, Small HJ, Neil DM, Feist SW (2002) Infection by a Hematodinium-like parasitic dinoflagellate causes pink crab disease (PCD) in the edible crab Cancer pagurus. J Invertebr Pathol 79:179-191

Stentiford GD, Evans M, Bateman K, Feist SW (2003) Coinfection by a yeast-like organism in Hematodiniuminfected European edible crabs Cancer pagurus and velvet swimming crabs Necora puber from the English Channel. Dis Aquat Org 54:195-202

Submitted: June 30, 2003; Accepted: October 27, 2003 Proofs received from author(s): April 8, 2004 